\title{
Adversity Intelligence as a Strategy to Increase the Readiness of Entrepreneurship Instrument
}

\author{
Kurjono \\ Universitas Pendidikan Indonesia \\ Bandung Indonesia \\ kurjono@upi.edu
}

\begin{abstract}
Readiness of entrepreneurship has a strong relationship to the level of entrepreneurial intention. The aim of research is to examine the effects of adversity intelligence with readiness of entrepreneurship instrument. Data were collected through questionnaires. The respondents in this research were students in a public university in Indonesia. The data were analyzed using Pearson-product moment correlation. The results of the study indicated that there was a positive and significant correlation between adversity intelligence and entrepreneurial intention. The analysis showed that the contribution of variable adversity intelligence to entrepreneurial intention was $11.45 \%$ while the remaining of $88.55 \%$ was explained by other factors. It is suggested that in the variable of Adversity Intelligence, the indicator of capabilities origin and ownership should be improved. In the variable of readiness of entrepreneurship instrument, the indicator of access to capital should be increased
\end{abstract}

Keywords-- Adversity Intelligence, instrument readiness, entrepreneurship

\section{INTRODUCTION}

Development of entrepreneurship recent years has become the issue of economic institutions ranging from local, national and even international. This is circumvented either by optimizing the entrepreneurship. The success of entrepreneurship education is the key to social outcomes is desirable, including harbor economy, lower unemployment, and technological modernization [1]. Entrepreneurship education is considered as one of the important factors to grow and develop a passion, spirit and entrepreneurial behavior among young people [2]. In connection with the importance of entrepreneurship education in its implementation in schools, required an understanding of how to develop the birth of young entrepreneurs, especially potential students at the university.

There is a tendency that they are low adversity intelligence affect to readiness instrument of entrepreneurship. In other words, readiness instrument of entrepreneurial is basic for student to be entrepreneur. Regarding the issue mentioned above, literature shows that there have been some research studies investigating readiness instrument entrepreneurial.

The readiness of the instrument and work experience before becoming a decisive factor for the students entrepreneurial intentions [3]. The empirical study earlier mentioned that the difficulty in gaining access to capital, credit schemes and constraints of the financial system is seen as a major obstacle to the success of businesses by prospective entrepreneurs in developing countries [4]. In developed countries highly efficient financial infrastructure, access to capital is also perceived as an obstacle to be the choice of self-employment because of the high barriers to entry to get a large capital to labor ratio. The access to capital becomes one of determining the success of a business [5]. By build adversity intelligence, the readiness instrument entrepreneurial can increase so they will increase entrepreneurial intention. In addition, the build adversity intelligence regarding the readiness of $e$ entrepreneurship instrument. However, adversity intelligence is still in question. Thus, a research investigating readiness instrument entrepreneurship is needed.

\section{A. Adversity Intellegence a Strategy to Increase Readiness of Entrepreneurship Instrument}

According to the Theory of Planned Behavior, two factors perceived desire to perform a behavior that personal attitudes (personal attitude) towards behavior and social norms (subjective norm) are perceived. Third perceived behavioral control (perceived feasibility), reflecting the perception that the behavior is controlled individually. Control behaviors reflect the perceived feasibility in performing a behavior and thus associated with the perception of competence situational. According to the theory, in the attitude toward the behavior, there are two fundamental aspects, namely: individual beliefs or not to display certain behaviors will result in the consequences or outcome-specific, and an aspect of the individual's knowledge of objects can also be the attitude of the individual opinion things that do not necessarily correspond to reality. The more positive individual beliefs would be the result of an attitude object, it will be positive also individual attitudes toward the attitude object, and vice versa [6]. In the process of learning is on the student implanted attitudes, especially attitudes towards entrepreneurship readiness instrument. Intelligence faces hurdles is the ability to turn obstacles into a chance of success goals [7]. Meanwhile, Adversity is the ability to think, manage and direct the actions that form a pattern of cognitive and behavioral responses of the stimulus events in life is a challenge or difficulty [8]. Intelligence in the face of obstacles individual has four dimensions, namely CO2RE (Control, Origin and Ownership, Reach and Endurance. Intelligence in the face of obstacles also affect the knowledge, creativity, productivity, performance, age, motivation, risk taking, repair, energy, vitality, stamina , health, and success in the job at hand [9]. 


\section{PRESS}

An individual who has the intelligence are more likely to face barriers profession as an entrepreneur because it has the ability to turn obstacles into opportunities [10]. Student have intellect faced obstacles tend to have the ability to bear the risk, the orientation of the opportunities / initiatives, creativity, independence and mobilization of resources, so Adversity Intelligence within the individual has a relationship with the desire for entrepreneurship.

The success of an entrepreneur in the learning process begins with preparedness instrument of entrepreneurial. Instruments readiness for entrepreneurial consists of the ability to access to capital, availability of information and social networks [11]. Low intention entrepreneurship in students as hesitant and afraid to fail so that they are not prepared to face obstacles. Thus the only people who dare to take risks and have the intelligence to face hurdles alone have a high entrepreneurial intentions.

Based on the pattern of the relationship of these variables, the higher the students who have the intelligence to face the challenge, the higher the readiness instrument of entrepreneurship, and vice versa.

\section{RESEARCH METODOLOGY}

This research investigates adversity intelligence and its influence to readiness instrument entrepreneurial. The independent variable of this research is adversity intellegence (X) comprising of Control, Origin and Ownership, reach and Endurance. Meanwhile the dependent variable readiness of entrepreneurship instrument (Y) comprising acces to capital, availability of information and social net.

Based on the aim and the variables stated above, this research is categorized as a descriptive and verificative research. This research tests the hypothesis of the influence of adversity intelligence to readiness of entrepreneurship instrument.

In line with the nature of the research, the unit of the analysis is student of accounting education. Meanwhile, since this research is categorized as descriptive and verifiable research, explanatory survey is used to get a general description of adversity intelligence to readiness of entrepreneurship instrument. The population of this research is student of accounting education. The samples, comprised of 91 respondents, are calculated by using Slovin formula. The sampling technique employed is simple random sampling while the data collection techniques used are questionnaire. In addition, the research applies product moment for data analysis and hypothesis testing technique.

\section{FINDING AND DISCUSSION}

Condition of variable adversity intelligence is medium. The high indicator is reach $78 \%$ and the low indicator is control $71,3 \%$ (Table 1).

Table 1

Description Adversity Intelligence

\begin{tabular}{|l|c|}
\hline \multicolumn{1}{|c|}{ Indicator } & $\%$ \\
Control & 71.3 \\
\hline Origin \& Ownership & 74.4 \\
\hline Reach & 78.5 \\
\hline Endurance & 71.6 \\
\hline
\end{tabular}

Source: data result

Condition of variable readiness of entrepreneurship instrument is medium. The high indicator is acces information as $77 \%$ and the low indicator is access to capital as $65 \%$ (table 2)

Table 2

Description Readiness of Entrepreneurship Instrument

\begin{tabular}{|c|c|}
\hline Indicator & $\%$ \\
\hline Access capital & 65 \\
\hline Social Net working & 71 \\
\hline Acces Information & 72 \\
\hline
\end{tabular}

Source: Data result

Empirically, based on the output of SPSS 16 program that is correlation 0.229 , and p-value $.029<0,05$, the result shows positive influence of adversity intelligence on readiness of entrepreneurship instrument. Hypothesis testing indicate that the adversity intelligence and significant positive effect on the readiness of entrepreneurship instrument. This means that the higher the adversity intelligence, the more positive the readiness of the instrument of entrepreneurial.

This research discusses the factors building readiness of entrepreneurship instrument its influence on adversity intelligence. The result of the hypothesis testing shows that $t-$ statistic score for adversity intelligence variable with $p$-value $0,029<0,05$. Therefore, it could be argued that the adversity intelligence comprising of indicators Control, Origin and Ownership, reach and Endurance. Has positive influence on readiness of entrepreneurship instrument.

The contribution to the R 2 The contribution of adversity intelligence variable to readiness entrepreneurship instrument as big as $5,24 \%$ while the remaining $94,76 \%$ is explained by other factors (figure 1)

\begin{tabular}{|l|l|r|r|}
\hline \multicolumn{3}{|c|}{ Correlations } \\
\hline $\mathrm{X}$ & Pearson Correlation & 1 & $.229^{*}$ \\
\cline { 2 - 4 } & Sig. (2-tailed) & & .029 \\
\cline { 2 - 4 } & $\mathrm{N}$ & 91 & 91 \\
\hline $\mathrm{Y}$ & Pearson Correlation & .229 & 1 \\
\cline { 2 - 4 } & Sig. (2-tailed) & .029 & \\
\hline \multicolumn{1}{|l|}{$\mathrm{N}$} & 91 & 91 \\
\hline \multirow{2}{*}{ *. Correlation is significant at the 0.05 level } \\
(2-tailed).
\end{tabular}

Fig 1: data result SPSS 16

Variable readiness instrument of entrepreneurial can be explained by the influence of adversity intelligence of 0, 229 in middle category, so it can be concluded that the readiness of entrepreneurship instrument positively affected by adversity intelligence. This means that the higher the intelligence, the more positive adversity readiness of entrepreneurship instrument. Adversity intelligence has relatively stable tendency to react to the practice of entrepreneurship of readiness instrument. Increased entrepreneurial attitude instrument which is the dependent variable can be predicted and explained by the independent variables that adversity intelligence. This is in accordance that cited difficulty in obtaining access to capital, credit schemes and constraints of 
the financial system is seen as a major obstacle to the success of businesses by prospective entrepreneurs in developing countries [12]. Likewise, states that access to capital becomes one of determining the success of a business [13].

These conditions indicate the medium of the interaction of adversity intelligence has a high level of readiness instrument of entrepreneurship. This is in accordance with the opinion, that intelligence is an ability to face obstacles to transform obstacles into a chance of success of achieving the goal [14]. The success of an entrepreneur in the learning process that begins with readiness instrument of entrepreneurship, particularly access to capital, availability of information and social networking. Students were able to overcome barriers to opportunities tend to have skills readiness instrument of readiness entrepreneurship.

The intensity of the interaction of the learning process of students in the challenges into opportunities in the world of work becomes one of the important aspects of adversity intelligence. Based on hypothesis testing, the higher intelligence of the challenge, the higher the readiness of entrepreneurship instrument, and vice versa.

Based on these results the importance of increasing adversity intelligence. Adversity intelligence should be improved and should be a concern the school, especially in preparing students for entering the world of entrepreneurship. Parents as well as heads of households should increase the insight, discipline and work ethic should also be introduced adversity intelligence in everyday life as a preparation to prepare for the future instrument entrepreneurship son of his daughter.

\section{CONCLUSION \& SUGGESTION}

Adversity intelligence positive effect on the readiness of entrepreneurship instrument. This means that the higher the adversity intelligence, the more positive readiness of entrepreneurship instrument accounting education student.

Adversity intelligence indicator is suggested that low is Control. It is enhanced through the learning process inserted in various subjects so that students know how much control we can feel to an event that raises difficulties. The most important thing of this dimension is the extent to which individuals may feel that such control plays a role in the events that lead to difficulties such as being able to control certain situations and so forth.

Likewise, it is suggested that indicator readiness of entrepreneurship instrument that low is improved access to capital. In the event that this can be done through the involvement of students interested in entrepreneurship to be active in the entrepreneurial incubator in college, as well through organized student Creativity Week Higher Education, so that access to capital for entrepreneurship students can be helped.

Of the four indicators of adversity intelligence of entrepreneurship, successively as follows: Reach (78\%), Origin and ownership (74\%), Endurance $(71,6 \%)$ and control (71.3\%). Of the four indicators above the Reach high, it indicates that the adversity intelligence Accounting Education students tend to have the ability of the extent of the difficulties encountered will reach other parts of the individual's life as a result of panic barriers, barriers due to lazy and so on.
The third indicator of the readiness of entrepreneurship instrument row as follows: Availability of information (72\%), social networking $(71 \%)$ and access to capital $(65 \%)$. Of the three indicators above, accounting education students tend to have the ability of the availability of information, namely access to information becomes a huge potential as a result of the interaction of the learning process.

\section{REFERENCE}

[1] Baumol, W. J., Litan, R. E., \& Schramm, C. J. (2007). Sustaining entrepreneurial capitalism. Capitalism and Society, 2(2) Article 1. Available at: http://www.bepress.com/cas/vol2/iss2/art1

[2] Kourilsky, M. L. dan W. B. Walstad, 1998. Entrepreneurship and female youth: knowledge, attitude, gender differences, and educational practices". Journal of Business Venturing 13 (1): 7788

[3] Indarti Rostiani, Intensi Kewirausahaan Mahasiswa: Studi Perbandingan Antara Indonesia, Jepang dan Norwegia, Jurnal Ekonomika dan Bisnis Indonesia, Vol. 23, No. 4, Oktober 2008

[4] Marsden, K., 1992. "African entrepreneurs - pioneer of development”. Small Enterprise Development 3 (2): 15-25.

[5] Meier, R. dan M. Pilgrim, 1994. "Policy-induced constraints on small enterprise development in Asian developing countries". Small Enterprise Development 5 (2): 66-78.

[6] Kristiansen, S., B. Furuholt, F. Wahid, 2003. "Internet café entrepreneurs: pioneers in information dissemination in Indonesia". The International Journal of Entrepreneurship and Innovation 4 (4): 251-263. et al. (2003)

[7] Indarti N, (2004) "Factors affecting entrepreneurial intentions among Indonesian students". Jurnal Ekonomi dan Bisnis 19 (1): 57-70.

[8] Ajzen, I. 1991. The Theory of Planned Behavior. Organizational Behavior and Human Decision Process, 50, 179-211

[9] Stoltz, 2000, Adversity Intellengence. Liberty: Yogyakarta.

[10] Surekha, 2001, Adversity Intellengence. Pustaka Umum: Jakarta

[11] Stoltz, 2000, Adversity Intellengence. Liberty: Yogyakarta

[12] Stoltz, 2000, Adversity Intellengence. Liberty: Yogyakarta.

[13] Indarti Rostiani (2008) Intensi Kewirausahaan Mahasiswa: Studi Perbandingan Antara Indonesia, Jepang dan Norwegia, Jurnal Ekonomika dan Bisnis Indonesia, Vol. 23, No. 4, Oktober 2008

[14] Marsden, K., 1992. "African entrepreneurs - pioneer of development”. Small Enterprise Development 3 (2): $15-25$.

[15] Meier, R. dan M. Pilgrim, 1994. "Policy-induced constraints on small enterprise development in Asian developing countries". Small Enterprise Development 5 (2): 66-78.

[16] Kristiansen, S., B. Furuholt, F. Wahid, 2003. "Internet cafe entrepreneurs: pioneers in information dissemination in Indonesia". The International Journal 
of Entrepreneurship and Innovation 4 (4): 251-263. et al. (2003)

[17] Indarti N, (2004) "Factors affecting entrepreneurial intentions among Indonesian students". Jurnal Ekonomi dan Bisnis 19 (1): 57-70.
[18] Stoltz, 2000, Adversity Intellengence. Liberty: Yogyakarta 